\title{
Effects of formaldehyde preservation on biometrical characters, biomass and biochemical composition of Acartia clausi (Copepoda, Calanoida)
}

\author{
K. Kapiris, H. Miliou \& M. Moraitou-Apostolopoulou* \\ Zoology and Marine Biology Laboratory, University of Athens; Panepistimiopolis, \\ Athens, 15784, Greece
}

\begin{abstract}
The effects of formaldehyde preservation on biometrical characters, biomass and biochemical composition of the marine copepod Acartia clausi were studied using the relevant values of fresh unpreserved animals as reference. Acartia were collected in the southern parts of Saronicos Gulf in early May $\left(16.5^{\prime \prime} \mathrm{C}\right)$ and late June $\left(21^{\prime \prime} \mathrm{C}\right)$. Formalin was found to cause significant shrinkage of cephalothorax length, abdomen length and total length. The sex of individuals, as well as the temperature of seawater at the time of collection seem to influence dimensıonal losses. Females and animals collected at $16.5^{\circ} \mathrm{C}$ presented heavier losses. Dry weight is drastically reduced after formaldehyde preservation. Final losses are more severe for females and animals collected at $21{ }^{\circ} \mathrm{C}$. Two of the measured biochemical constituents, carbohydrates and neutral lipids, seem to be unaffected by formaldehyde. DNA and RNA although initially affected seem to be stabilized towards the end of the experimental period (30 days). The other biochemical parameters, viz proteins, total lipids and sugars, are profoundly affected by preservation.
\end{abstract}

\section{INTRODUCTION}

Studies on the growth, energetics and production of marine planktic animals require precise measurements of dry weight and chemical composition. Dry weight is widely used as a measure of biomass for zooplanktic organisms. Taxonomic, morphological and ecological studies also include dimensional and biomass parameters. Recently, the assumption has evolved that size per se influences the form and function of organisms from physiology and functional morphology to ecological characters. As a result, the field of scaling, the study of the influence of body size on form and function, has become a prominent focus in ecology and evolutionary biology, emphasizing the need for biometrical measurements (La Barbera, 1989).

The knowledge of biochemical composition is important when quantifying transformation processes of zooplankton through pelagic food webs. It also provides the information necessary for evaluating bioenergetic relationships, which may be key factors in the evolution of different life strategies. Quantitative analysis of RNA has been used to estimate growth rates (Sutcliffe, 1970; Bamstedt \& Skjoldal, 1980).

Ideally, any biometrical measurement, biomass estimation and biochemical analysis of zooplankton should be based on fresh, unpreserved material. However, in the marine

\footnotetext{
- Addressee for all correspondence

(1) Biologische Anstalt Helgoland, Hamburg
} 
field an immediate sorting of sampled material, as well as any subsequent process are almost impossible. Thus, biometrical, biomass and biochemical parameters are mostly determined from preserved planktic organisms. Chemical preservation is considered the most suitable because it can be used conveniently in the field without technical devices. However, comparative studies have shown that fixation with formaldehyde, the most commonly used preservative, generally results in an alteration of the measured parameters e.g. loss of weight (see Giguere et al., 1989 for a review of literature).

In this study we attempt to find out how preservation in formaldehyde, the most widely used plankton preservation method, affects dimensional characters, biomass estimation and biochemical composition of zooplankton. Thus, we have performed comparative measurements of biometrical characters (cephalothorax length, abdomen length, total length), biomass (dry weight) and biochemical composition (lipids, proteins, sugars, carbohydrates, RNA, DNA) of unpreserved and of Formalin-preserved specimens of the copepod Acartia clausi.

\section{MATERIAL AND METHODS}

Zooplankton sampling was performed by horizontal hauls using a WP2 net in the south of Saronicos Gulf (Agios Kosmas area). Samples were collected in early May and late June 1991 when seawater temperature was $16.5^{\circ} \mathrm{C}$ and $21^{\circ} \mathrm{C}$, respectively.

The plankton catches were divided into two parts: one aliquot was preserved in $4 \%$ Formalin buffered with borax ( $2 \mathrm{~g}$ of borax to $98 \mathrm{ml}$ of $40 \%$ formaldehyde according to UNESCO's WG 23 formula (Steedman, 1976)]. The other aliquot was transferred alive to the laboratory and analysed immediately. Fresh plankton was narcotized using $\mathrm{MgCl}_{2}$. This procedure permitted the sorting of mature females and males of Acartia clausi. All sorted Acartia specimens were rinsed with ammonium formate isotonic $(0.9 \%)$ to seawater to remove seawater salts.

Acartia clausi is a very common and ecologically important copepod species of Saronicos Gulf (Moraitou-A postolopoulou, 1971, 1974).

Biometrical measurements. The following dimensional characters of Acartia were measured under a Wild M5 microscope equipped with a calibrated micrometer ocular: cephalothorax length (Lth.), abdomen length (Labd.) and total length (Ltot.). For every dimensional character and for each one of the experimental conditions, 100 females and 100 males were measured. Two series of measurements corresponding to the two sampling periods were realized. Biometrical measurements were performed on fresh nonpreserved Acartia ( 0 days) and on Acartia preserved for varying periods $(2,4,6,8,10,12$, $14,16,32,48,64$ and 80 days).

Biomass estimation. The biomass of Acartia was estimated by calculation of the dry weight, which is the most reliable biomass index. Measurements were realized in fresh unpreserved Acartia and in Acartia preserved for various periods, the same as for the biometrical measurements. Here also two series of measurements corresponding to the two sampling periods were performed.

Dry weight was estimated according to the method of Mazza (1964). 100 females and 100 males were used for each measurement. Acartia specimens were dried on aluminium planchets in an oven at $60^{\circ} \mathrm{C}$ for $24 \mathrm{~h}$ until constant weight was achieved. The dried samples were stored in desiccator cabinets with silica gel as desiccant. The copepods were then weighed on a Sartorius balance (type 1801, accuracy: $0.1 \mathrm{mg}$ ). 
Biochemical composition. The biochemical analysis of Acartia was performed using females collected during May. Measurements were carried out on fresh unpreserved material (0-f) and in Acartia preserved for various periods, immediately $(0+F)$ and 2, 10, 20 and 30 days. Each sample for biochemical analysis consisted of 500 mature females of Acartia and had a dry weight of 5-10 $\mu \mathrm{g}$ (weighed on a Mettler M3 microelectrobalance - precision $0.1 \mu \mathrm{g}$ ).

All samples were washed with an isotonic solution of ammonium formate $(0.9 \%)$ and put in Eppendorff polyethylene reaction tubes. They were then lyophilised and kept at $-40^{\circ} \mathrm{C}$.

As samples were small we followed the microanalytical scheme for the determination of proteins, total lipids, neutral lipids, carbohydrates, sugars, RNA and DNA, described by Holland \& Gabbot (1971) and modified by Holland \& Hannant (1973) by adding in the fractionation the neutral lipid and DNA.

For each studied condition one sample was prepared. The dried sample was homogenised with $500 \mu l$ distilled and deionised water. The total end product analyses were carried out according to Holland \& Hannant (1973). These were, in total, 20 for proteins, 3 for total lipid and DNA, 2 for carbohydrates, sugars and neutral lipid and 6 for RNA. The extinction was measured with a spectrophotometer, after correction for the absorbance at the appropriate reagent blank.

The concentration was estimated from the standard curves calculated (linear regression analysis) for each method. These curves are as follows:

$$
\begin{aligned}
& \text { 1. Lipid (Standard : tripalmitin) } \\
& Y=-6.187+152.508 \mathrm{x} ; \mathrm{r}=0.83 \\
& \text { 2. Protein (Standard : Ammonium sulphate) } \\
& \mathrm{Y}=-109.72+1026.3 \mathrm{x} ; \mathrm{r}=0.82 \\
& \text { 3. Total carbohydrates }- \text { Sugars (Standard : Glucose) } \\
& \mathrm{Y}=10.45-143.71 \mathrm{x} ; \mathrm{r}=0.97 \\
& \text { 4. RNA (Standard : RNA yeast) } \\
& \mathrm{Y}=-2.11+67.02 \mathrm{x} ; \mathrm{I}=0.99 \\
& \text { 5. DNA (Standard }: \text { Calf thymus) } \\
& \mathrm{Y}=-10.43+97.42 \mathrm{x} ; \mathrm{r}=0.96
\end{aligned}
$$

The significance of differences in the biometrical measurements and the biochemical composition was tested by the $F$-test. If $F$-ratio values are higher than $F_{0.05}(P<0.05)$, the variance among the groups (non preserved or preserved for different periods) is higher than that within the groups (measurements of various individuals of the same condition). For the comparison of means among the measurements taken at different preservation periods, one-way analysis of variance was performed (Tukey's method) for each sex and sampling temperature. The $95 \%$ Tukey HSD (honesty significant difference) intervals for means were calculated and the homogeneous groups were confirmed by multiple range analysis (Sokal \& Rohlf, 1981).

The main effects and the interaction of duration of preservation and temperature were estimated by two-way ANOVA for each sex and they are significant if $F>F_{0.05}$ $(\mathrm{P}<0.05)$.

The statistical analysis was carried out on a P.C., using Statgraphics statistical package. 


\section{RESULTS}

The mean values of the measured biometrical characters of Acartia clausi and their evolution during the 80 days of formaldehyde preservation are shown in Figure 1. A decrease of all measured body dimensions was noticed in animals preserved in Formalin. This decrease was more important for the first two to four days. Afterwards, a less intense and an irregular, i.e fluctuating, reduction of body dimensions takes place. A stabilization seems to occur in about the middle of the experimental period, and this stabilization takes place earlier for the animals collected at $21{ }^{\circ} \mathrm{C}$.

Table 1 presents the results of the one-way analysis of variance and the final percentage of dimensional losses. In all cases the values of F-ratio are higher than $F_{0.05}$ (12. $1287=1.75$. This means that the variance among the groups is higher than the variance between the groups. The differences are significant at $P=0.0000$ in all cases.

Table 1. Values of F-ratio computed by one-way analysis of variance for the Lth., Labd. and Ltot. of female and male Acartia clausi measured for 13 different preservation times $\left(\mathrm{df}_{\mathrm{rum}}=12\right)$ in groups of 100 individuals $\left(\mathrm{df}_{\text {denomm }}=1287\right)$. In all cases $\mathrm{P}=0.0000 ; \mathrm{H} . \mathrm{G} .=$ number of homogeneous groups (Tukey's test); "\% Loss = \% total length loss from the initial measurement of fresh animals till the mean value of the last homogeneous group of Formalin-preserved animals towards the end of the experiment

\begin{tabular}{|c|c|c|c|c|c|}
\hline Temperature & Sex & Length & F-ratio & H.G. & $1 \%$ Loss \\
\hline \multirow{6}{*}{$16.5^{\circ} \mathrm{C}$} & \multirow{3}{*}{ Female } & Lth. & 79.528 & 6 & 15.11 \\
\hline & & Labd. & 133.753 & 6 & 30.20 \\
\hline & & Ltot. & 123.441 & 6 & 13.99 \\
\hline & \multirow{3}{*}{ Male } & Ith & 63615 & 8 & 806 \\
\hline & & Labd. & $\begin{array}{r}03.013 \\
127.679\end{array}$ & $\begin{array}{l}0 \\
4\end{array}$ & $\begin{array}{r}0.90 \\
27.55\end{array}$ \\
\hline & & Ltot. & 103.578 & 7 & 12.31 \\
\hline \multirow{7}{*}{$21^{\circ} \mathrm{C}$} & \multirow{3}{*}{ Female } & Lth. & 70.229 & 7 & 11.37 \\
\hline & & Labd. & 10.740 & 4 & 10.28 \\
\hline & & Ltot. & 28.240 & 6 & 5.90 \\
\hline & \multirow{4}{*}{ Male } & & & & \\
\hline & & Lth. & 19.838 & 4 & 4.43 \\
\hline & & Labd. & 6.513 & 3 & 7.19 \\
\hline & & Ltot. & 17.358 & 5 & 4.93 \\
\hline
\end{tabular}

Animals collected at $16.5^{\circ} \mathrm{C}$ presented a more pronounced shrinkage of all body dimensions than those collected at $21^{\circ} \mathrm{C}$. Thus, although Acartia gathered at $16.5^{\circ} \mathrm{C}$ had, according to measurements made on fresh material, higher body dimensions, after some days of Formalin preservation, Acartia from both temperatures presented similar values of body dimensional characters. The lower F-ratio values noticed for the animals collected at $21^{\circ} \mathrm{C}$ (ANOVA) resulted from the lower losses and the earlier stabilization of all measured dimensions, for both sexes at this temperature.

Furthermore, the sex of individuals but also the type of the measured dimensional character seem to influence dimensional losses. Females usually suffer more losses than males. This becomes particularly true for the abdomen length which is the biometrical 

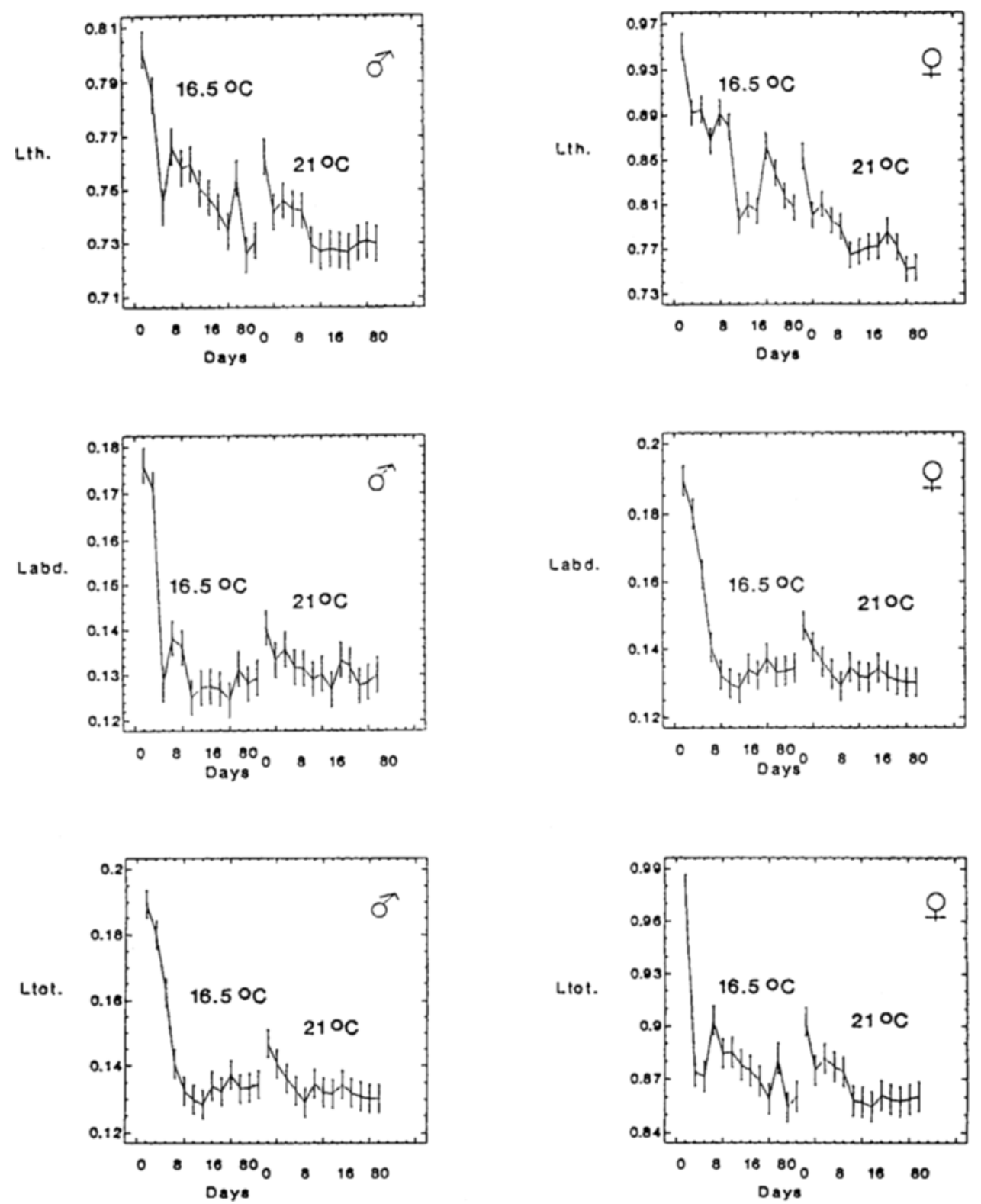

Fig. 1. Mean values and $95 \%$ Tukey HSD intervals of Lth., Labd. and Ltot. ( $\mathrm{mm}$ ) of female and male Acartia clausi collected at two different temperatures, $16.5^{\circ} \mathrm{C}$ and $21^{\circ} \mathrm{C}$, and measured fresh $(0$ days) and at 12 different preservation times: $2,4,6,8,10,12,14,16,32,48,64$ and 80 days 
character presenting the heavier losses. The F-ratio values for females ANOVA are higher than those for males for all measured dimensions at both temperatures.

Table 2 presents the results of the two-way analysis of variance for the effects of the two main factors: duration of Formalin preservation and temperature of collection. The measured dimensions of both males and females differ significantly according to temperature $\left(F>F_{0.05}(12,2574)=3.84\right)$ and duration of Formalin preservation $\left(F>F_{0.05(12,2574)}=\right.$ 1.75). The interaction of these two factors is significant in all cases $\left(F>F_{0.05}(12,2574)=1.75\right)$. Temperature at the time of sampling proved to be a more decisive factor than duration of preservation giving higher F-ratio values and affecting above all the abdomen length.

Table 2. Values of F-ratio computed by two-way analysis of variance for the main effects of specimen's preservation in Formalin for varying periods (13 groups of measurements of each dimension, $\mathrm{df}=12)$ and collection's temperature (2 temperatures $16.5^{\circ} \mathrm{C}$ and $\left.21^{\prime \prime} \mathrm{C}, \mathrm{df}=1\right)$ and their interactions $(\mathrm{df}=12)$ in samples of 100 individuals (df residual $=2.574$ ) separated for male and female Acartid clausi. In all cases $\mathrm{P}=0.0000$

\begin{tabular}{|clccc|}
\hline \multirow{2}{*}{ Sex } & Length & Duration & Temperature & $\begin{array}{c}\text { Two factors } \\
\text { interactions }\end{array}$ \\
\hline \multirow{3}{*}{ Female } & Lth. & 134.216 & 1000.00 & 19.651 \\
& Labd. & 113.416 & 233.168 & 48.922 \\
& Ltot. & 140.356 & 648.070 & 29.956 \\
& & & & \\
Male & Lth. & 70.840 & 332.827 & 17.693 \\
& Labd. & 89.169 & 639.140 & 51.383 \\
& Ltot. & 90.550 & 143.723 & 23.482 \\
\hline
\end{tabular}

Figure 2 shows the dry-weight values of fresh, non-preserved Acartia and their evolution during the 80 days of Formalin preservation. The dry weight of both females and males is drastically reduced after formaldehyde preservation, dropping to about half its initial value after two days of preservation. Thereafter, some fluctuations occur. Stabilization of dry weight takes place faster in the animals collected at $21{ }^{\circ} \mathrm{C}$. Final losses are heavier for the females $(66.6 \%)$ than for the males $(50 \%)$. Acartia collected at $21{ }^{\circ} \mathrm{C}$ bear heavier losses. Here, also females lose more $(85.7 \%)$ than males $(71.42 \%)$ and values of dry weight present some fluctuations till about the end of the experimental period.

ANOVA analysis (Fig. 3) proved that the percentage dry-weight losses during preservation of females and males collected at both examined temperatures show significant differences $(\mathrm{F}(3,44)=10.752, \mathrm{P}=0.0000)$.

Figure 4 illustrates the mean values of the measured biochemical constituents of females of Acartia and their evolution after formaldehyde preservation, whereas Table 3 gives the results of one-way analysis of variance for the observed variations. All biochemical parameters seem to be affected immediately by Formalin. However, for two of them - carbohydrates and neutral lipids - the variations observed proved to be not significant $(\mathrm{P}>0.05)$. The DNA content, although significantly affected in all measurements till day 20, returns to its initial value when measured on day 30 . The RNA content is also significantly affected immediately. However, the measurements of days 10 and 30 show 

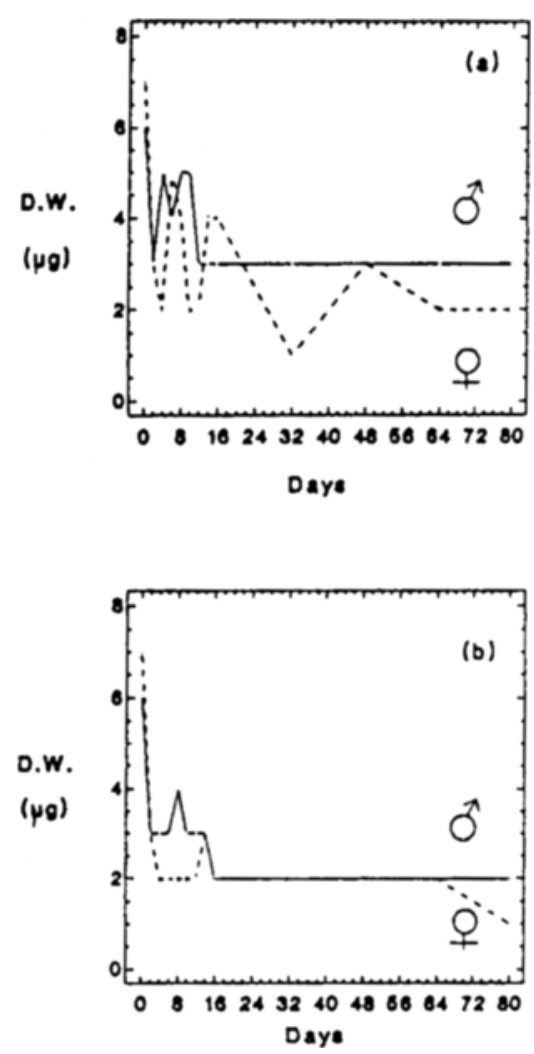

Fig. 2. Values of dry weight per individual ( $\mu \mathrm{g})$ of female and male Acartia clausi: fresh (0 days) and preserved in Formalin for $2,4,6,8,10,12,14,16,32,48,64$ and 80 days, and collected at two different temperatures, $16.5^{\circ} \mathrm{C}$ (a) and $21^{\circ} \mathrm{C}(\mathrm{b})$

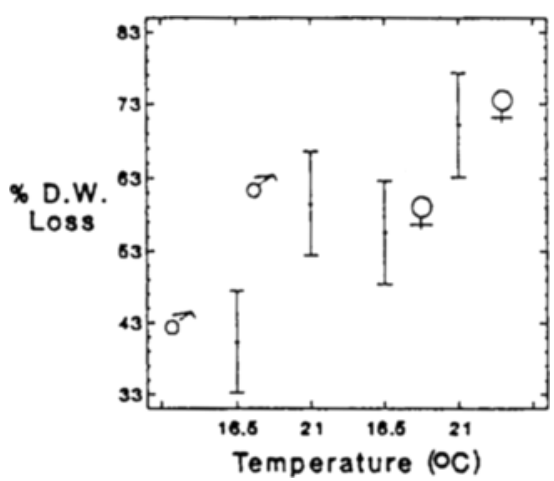

Fig. 3. Mean values and 95\% Tukey HSD intervals of the percentage loss of dry weight during Formalin preservation of male and female Acartia clausi collected at two different temperatures, $16.5^{\circ} \mathrm{C}$ and $21^{\circ} \mathrm{C}$ 
Table 3. Values of F-ratio computed by one-way analysis of variance for the biochemical constituents of female Acartia clausi collected at $16.5^{\circ} \mathrm{C}$ and analysed fresh and preserved in Formalin for 5 different time periods

\begin{tabular}{|lrrrrrr|}
\hline & \multicolumn{7}{c}{ D. F. } & & & $\begin{array}{c}\text { Composition } \\
\%\end{array}$ \\
\hline F-ratio & nom. & denom. & $P$ & H.G. & 10 \\
N. lipids & 3.556 & 5 & 11 & 0.0371 & 2 & 5 \\
Proteins & 2.479 & 4 & 4 & 0.2004 & 1 & 70 \\
Sugars & 103.279 & 5 & 123 & 0.0000 & 3 & 0.97 \\
Carbohydrates & 13.571 & 5 & 15 & 0.0000 & 2 & 1.47 \\
DNA & 25.452 & 5 & 1 & 0.1473 & 1 & 2.31 \\
RNA & 4.713 & 5 & 12 & 0.0130 & 2 & 34 \\
& 40.114 & 5 & 24 & 0.0000 & 3 & \\
\hline
\end{tabular}

values insignificantly different from the initial value, but in the measurement of day $20 \mathrm{a}$ higher and significantly different value was noticed.

For the other biochemical constituents, strong and statistically significant differences $(\mathrm{P}<0.05)$ from the values of non preserved animals have been observed up to the end of the experimental period. For sugars, a strong decrease was noticed, while for total lipids and protein content, curiously, an important increase was measured.

\section{DISCUSSION}

Results of the present study have shown that plankton preservation using Formalin causes an alteration of almost all measured biometrical, biomass and biochemical parameters.

During fixation with formaldehyde, body fluids are either leached from the copepods, or are exchanged with the surrounding preservative fluid. Formalin interacts also with cellular constituents, resulting in the formation of new substances. Changes in the course of this process could eventually explain the observed fluctuations of biometrical measurements. The use of $4 \%$ formaldehyde solution more than doubles the osmotic pressure of seawater (Steedman, 1976; Williams \& Robins, 1982), and the hyperosmotic pressure could cause loss of body fluids.

Alterations may also derive from the use of ammonium formate for rinsing, although isotonic ammonium formate was used which is expected to prevent leaching to the external fluid. According to Omori (1978), this procedure has produced a wide range of variation attributed to impurities in the reagents or to incomplete volatization of ammonium formate. Isotonic ammonium formate rinse resulted in lower organic weight and chemical contents compared with samples rinsed with filtered seawater.

Due to the different rinsing methods used, the weights of copepods are usually underestimated to a varying degree. As this effect is generally more pronounced in unpreserved material compared with fixed material, the loss of weight due to fixation tends to be underestimated as well (Böttger \& Schnack, 1986).

Results published on the possible changes in copepods lengths caused by Formalin preservation (Landry, 1978; Durbin \& Durbin, 1978; Williams \& Robins, 1982) show that this effect, if present, is minor. Therefore, calculations in the literature concerning weight 

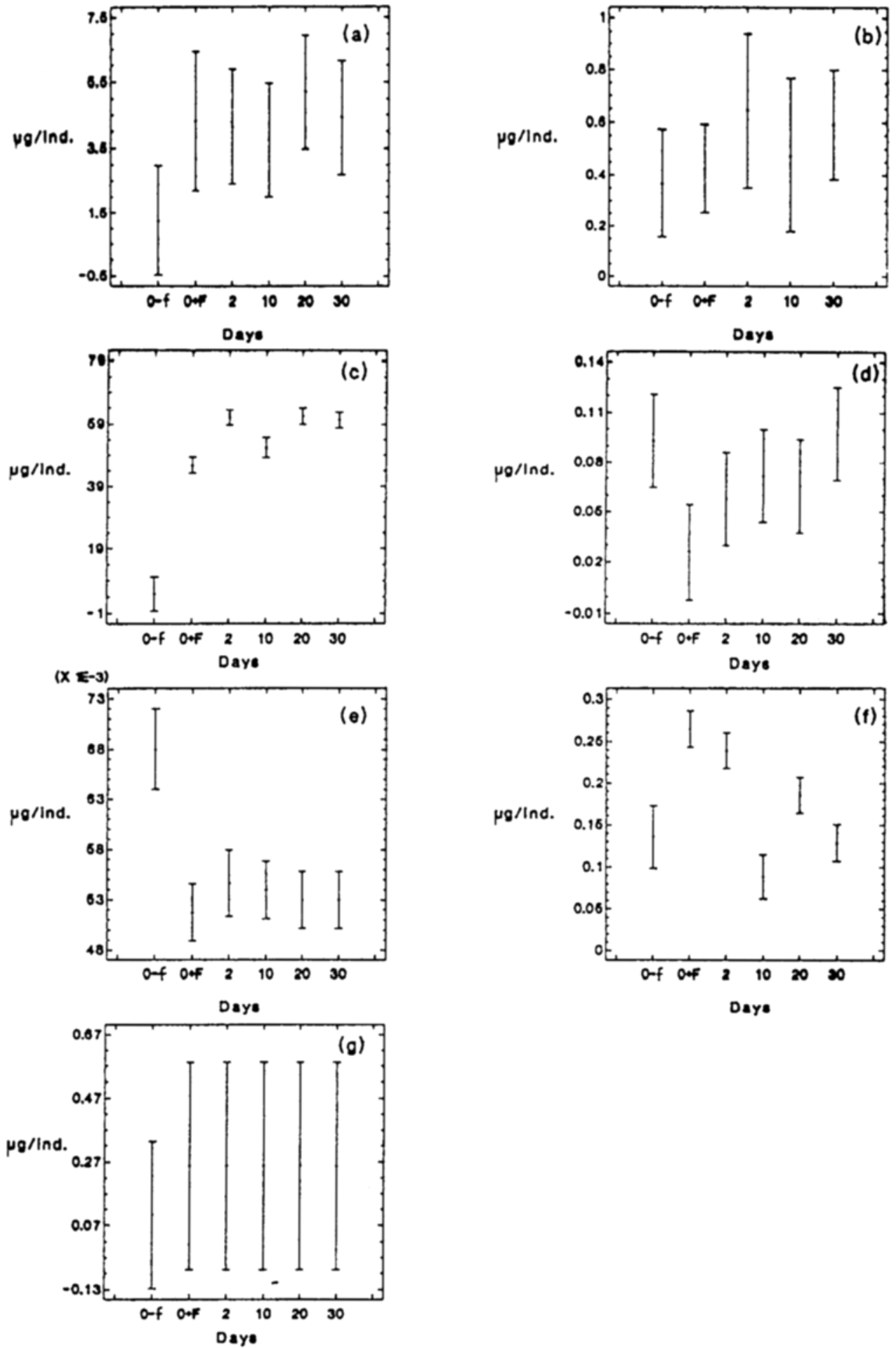

Fig. 4. Mean values and $95 \%$ Tukey HSD intervals of the biochemical constituent's content ( $\mu$ g/individual) of female Acartia clausi, collected at $16.5^{\circ} \mathrm{C}$ and analysed fresh $(0-f)$ and preserved in Formalin $(0+F, 2,10,20,30$ days). Lipids (a), neutral lipids (b), proteins (c), DNA (d), sugars (e), RNA (f), carbohydrates (g) 
losses after Formalin preservation (Durbin \& Durbin, 1978; Böttger \& Schnack, 1986) have been based on the assumption that the prosome lengths are not affected by the fixation. However, our results have shown that all measured biometrical characters, even the cephalothorax length, may present significant reduction after Formalin preservation.

Shrinkage of fish larvae due to Formalin fixation has been reported in the literature (Lockwood \& Daly, 1975; Schnack \& Rosenthal, 1978; Hay, 1981). Acartia collected at $16.5^{\circ} \mathrm{C}$ presented higher percentages of losses for all measured biometrical characters compared with Acartia collected at $21^{\circ} \mathrm{C}$. This could be partly attributed to differences caused by the variations of environmental factors between the two sampling periods. Hay (1982) concluded that salinity affects body shrinkage in herring larvae.

The dimensional differences between Acartia collected at $16.5^{\circ} \mathrm{C}$ and $21^{\circ} \mathrm{C}$ is a well known phenomenon, and there are pronounced seasonal differences in body size among marine copepods. Length is inversely correlated with ambient temperature (Vucetic, 1965; Moraitou-Apostolopoulou, 1969, 1975; Razouls \& Guiness, 1973).

A substantial amount of variation exists in the literature concerning dry-weight losses of planktic animals after Formalin preservation. After Giguere et al. (1989), the published estimates of dry-weight loss due to chemical preservation range widely (from $9.0 \%$ to $63.8 \%$. The variation could be due to differences in the biochemical composition of the arganisms (species, body size, physiological condition) and/or methodological differences (length of preservation, concentration or type of the preservative, buffering agent, weighing, drying or rinsing method). Species-specific, season-specific and sexspecific effects appear to be important. Dry-weight losses are somewhat size-dependent, smaller plankton losing more.

From our results it is shown that differences in weight loss are related to the sex of individuals, females always losing more. This is in accordance with previous literature data (Durbin \& Durbin, 1978; Champalbert \& Kerambrun, 1979; Williams \& Robins, 1982). The previous life history also seems to influence weight loss, as animals collected at $21^{\circ} \mathrm{C}$ suffer much heavier losses than those collected at $16.5^{\circ} \mathrm{C}$. Temperature also seems to be an outstanding factor controlling weight losses.

Values of dry-weight losses noticed at $16.5^{\circ} \mathrm{C}$ are approximately in the range reported in the literature, while very heavy losses were noticed at $21^{\circ} \mathrm{C}$. The observed differences in dry-weight loss at the two temperatures could, in part, be attributed to differences in the body constituents of Acartia. The chemical composition of zooplankton varies, within a certain range, depending on environmental and other factors, e.g. nutritional history, ontogenetic stage and sex. Bamstedt (1983) refered seasonal variation in the RNA content of zooplankton to seasonal variation of food supply.

In our results there is an apparent discrepancy as length losses of Acartia are more significant in the $16.5^{\circ} \mathrm{C}$ animals, while dry-weight losses are more pronounced for the $21^{\circ} \mathrm{C}$ Acartia. This could be attributed to the fact that length losses are greater in the abdomen than in the cephalothorax or in total length. The abdomen of the $16.5^{\circ} \mathrm{C}$ Acartia is longer than that of $21^{\circ} \mathrm{C}$ because Acartia at $16.5^{\circ} \mathrm{C}$ is not only longer but also the proportion of the abdomen to the whole body length is higher in the Acartia of $16.5^{\circ} \mathrm{C}$.

The biochemical composition of fresh, non preserved, Acartia shown in Table 3 is in accordance with the data of literature (Bamstedt, 1986). Two of the measured biochemical constituents of Acartia, i.e. carbohydrates and neutral lipids, seem to be unaffected by Formalin preservation and therefore could be measured from preserved material. RNA 
and DNA content, although initially affected, seem to become stabilized soon (within 30 days, which was the duration of our experience) returning to values not significantly different from those of fresh material. Therefore, they could then be measured, with reservation, from preserved material. This is important because RNA content tends to be used as an indicator of rates of growth (Sutcliffe, 1970). However, need for more prolonged measurements seems clear.

Stability of RNA during prolonged storage in ethanol has been observed by Bamstedt (1983).

The other biochemical constituents measured, namely proteins, total lipids and sugars, seem to be affected profoundly by preservation, and their quantitative changes remained constant till the end of our experimental period. Formaldehyde has the property to be fixed on aminogroups. Morris (1972) and Jones (1976) concluded that preservation results also in hydrolysis of lipids and degradation of polyunsaturated fatty acids in zooplankton.

The percentage loss of $N$ and C, reported by Hopkins (1968), Omori (1978), Champalbert \& Kerambrun (1979) and Williams \& Robins (1982) in their studies with zooplankton preserved with different preservatives, buffering agents and for different durations, ranged from 20 to $49 \%$ and from 13 to $29 \%$, respectively. In our results, a very important increase of protein content was noticed. The discrepancy could be attributed to methodological problems, as Beers (1976) states that nitrogen lost from preserved material was due to a loss of free amino acids and smaller nitrogenous molecules.

In the literature (Fudge, 1968; Hopkins, 1968; Omori, 1978; Champalbert \& Kerabrun, 1979; Williams \& Robins, 1982), it is reported that Formalin seems unsuitable as a preservative for biochemical analysis. Use of preserved material should be made after appropriate adjustments. However, from our results it is shown that preserved material could be used for some biochemical parameters, such as neutral lipids and carbohydrates, eventually also for RNA, DNA, which play an important role in ecological studies.

The loss of dimensional characters and dry weight after preservation in Formalin emphasizes the need to take into account such losses when estimating biometrical characters and biomass from preserved samples. According to the present study, some other factors such as seawater temperature at the time of collection and, consequently, the initial size of animals also seem to produce these losses.

\section{LITERATURE CITED}

Bamstedt, U., 1983. RNA concentration in zooplankton: seasonal variation in boreal species. - Mar. Ecol. Prog. Ser. 11, 291-297.

Bamstedt, U., 1986. Chemical composition and energy content. In: The biological chemistry of marine copepods. Ed. by E.D.S. Corner \& S.C.M. O'Hara. Clarendon Press, Oxford, 1-58.

Bamstedt, U. \& Skjoldal H. R., 1980. RNA concentration in zooplankton: Relationship with size and growth. - Limnol. Oceanogr. 25, 304-316.

Beers, J. R., 1976. Determination of zooplankton biomass. In: Zooplankton fixation and preservation. Ed. by H. F. Steedman. Unesco Press, Paris, 35-84.

Böttger, R. \& Schnack D., 1986. On the effects of formaldebyde fixation on the dry weight of copepods. - Meeresforschung 31, 141-152.

Champalbert, G. \& Kerabrun P., 1979. Influence du mode de conservation sur la composition chimique élémentaire de Pontella mediterranea (Copepoda, Pontellidae). - Mar. Biol. 51, 357-360.

Durbin, E. \& Durbin A., 1978. Length and weight relationships of Acartia clausi from Narraganseft Bay, R.I. - Limnol. Oceanogr. 23, 958-969. 
Fudge, H., 1968. Biochemical analysis of preserved zooplankton. - Nature, Lond. 219, 380-381.

Giguere, L.A., St-Pierre, J.F., Bernier, B., Vezina, A. \& Rondeau, J.G., 1989. Can we estimate the true weight of zooplankton samples after chemical preservation? - Can. J. Fish. aquat. Sci. 46, 522-527.

Hay, D.E., 1981. Effects of capture and fixation on gut contents and body size of Pacific herring larvae. - Rapp. P.-v. Réun. Cons. int. Explor. Mer 178, 395-400.

Hay, D.E., 1982. Fixation shrinkage of herring larvae: effects of salinity, formalin concentration and other factors. - Can. J. Fish. aquat. Sci. 39, 1138-1143.

Holland, D.L. \& Gabbott, P.A., 1971. A micro-analytical scheme for the determination of protein, carbohydrate, lipid and RNA levels in marine invertebrate larvae. - J. mar. biol. AsS. U.K. 51, $659-668$

Holland, D.L. \& Hannant P.J., 1973. Addendum to a micro-analytical scheme for the biochemical analysis of marine invertebrate larvae. - J. mar. biol. Ass. U.K. 53, 833-838.

Hopkins, T.L., 1968. Carbon and nitrogen content of fresh and preserved Nematoscelis difficilis, a euphausiid crustacean. - J. Cons. perm. int. Explor. Mer 31, 300-304.

Jones, D., 1976. Chemistry of fixation and preservation with aldehydes. in: Zooplankton fixation and preservation. Ed. by H.F. Steedman. Unesco Press, Paris, 155-171

La Barbera, M., 1989. Analysing body size as a factor in ecology and evolution. - A. Rev. Ecol. Syst. 20,97-127.

Landry, M.R., 1978. Population dynamics and production of a planktic marine copepod Acartia clausi, in a small temperate lagoon in San Juan Island, Washington, - Int. Revue ges. Hydrobiol. 63, 77-119.

Lockwood, S. J. \& Daly, C. de B., 1975. Further observations on the effects of preservation in $4 \%$ neutral formalin on the length and weight of O-group flatfish. - J. Cons, perm. int. Explor. Mer 36, $170-175$

Mazza, J., 1964. Premières observations sur les valeurs du poids sec chez quelques copépodes de Méditerranée. - Revue Trav. Inst. Pèch. marit. 28, 293-301.

Moraitou-Apostolopoulou, M., 1969. Variability of some morphoecological factors in six pelagic copepods from the Aegean Sea. - Mar. Biol. 3, 1-13.

Moraitou-Apostolopoulou, M., 1971. Vertical distribution, diurnal and seasonal migration of copepods in Saronic Bay, Greece. - Mar. Biol. 9, 92-99.

Moraitou-Apostolopoulou, M., 1974. An ecological approach to the systematic study of planktic copepods in a polluted area. - Boll. Pesca Piscic. Idrobiol. 29, 29-47.

Moraitou-Apostolopoulou, M., 1975. Seasonal variations in length of three copepods in Saronic Bay. - Boll. Pesca Piscic. Idrobiol. 30, 93-101.

Morris, R.J., 1972. The preservation of some oceanic animals for lipid analysis. - J. Fish Res. Bd Can. 29, 1303-1307.

Omori, M., 1978. Some factors affecting dry weight, organic weight and concentration of carbon and nitrogen in freshly prepared and in preserved zooplankton. - Int. Revue ges. Hydrobiol. 63, 261-269

Razouls, C. \& Guiness, C., 1973. Variations annuelles quantitatives de deux espèces dominantes de copépodes planctoniques Centropages typicus et Temora stylifera de la région de Banyuls. Cycles biologiques et estimation de la production. Il Variations dimensionelles et mésure de croissance. - Cah. Biol mar. 14, 413-427.

Schnack, D. \& Rosenthal, H., 1978. Shrinkage of Pacific herring larvae due to formalin fixation and preservation. - Ber. dt. Wiss. Kommn Meeresforsch. 26, 222-226.

Sokal, R. \& Rohlf, J., 1981. Biometry. Freeman, New York, 859 pp.

Sutcliffe, W. H., 1970. Relationship between growth rate and ribonucleic acid concentration in some invertebrates. - J. Fish. Res. Bd Can. 27, 606- 609

Steedman, H. F. (Ed.), 1976. Zooplankton fixation and preservation. Unesco, Paris, 350 pp.

Williams, R. \& Robins, D.B., 1982. Effects of preservation on net weight, dry weight, nitrogen and carbon contents of Calanus helgolandicus . - Mar. Biol. 71, 271-281.

Vucetic, T., 1965. Quelques données sur la longueur des adultes de Calanus helgolandicus Claus, provenant de Veliko Jejero (Mljet). - Rapp. P.-v. Réun. Commn int. Explor. scient. Mer Méditerr. $18,431-438$ 